\title{
DAMPAK KOMPETENSI GURU DAN PERAN MOTIVASI DALAM MENENTUKAN KINERJA GURU DI YAYASAN PENDIDIKAN GMI IMANUEL
}

\author{
Retno Dewanti'; Tjia Fiechu²; Meriana ${ }^{3}$ \\ 1,2,3 Jurusan Manajemen, Fakultas Ekonomi dan Bisnis, Bina Nusantara University \\ Jln. K.H. Syahdan No. 9, Kemanggisan, Palmerah, Jakarta Barat 11480 \\ rdewanti@binus.edu, fiechu@binus.edu, loha_meri@yahoo.com
}

\begin{abstract}
Educational success is largely determined by the performance of teachers in education. This study aims to examine the contribution of teacher competencies and motivation role in determining the teacher performance. The population in this study were teachers GMI Emmanuel Education Foundation by 74 people. Instruments used in this study was a questionnaire enclosed, was tested with test validity and reliability. The method analysis used discriminant analysis, cluster analysis, Regression, and Path Analysis. The results of cluster analysis showed most teachers who have a positive attitude toward the teacher performance variables. The results of path analysis showed that the research hypothesis accepted in the sense that there are significantly contribution among exogen variables and endogen variable.
\end{abstract}

Keywords: background, organization, motivation, teacher competencies, performance

\begin{abstract}
ABSTRAK
Keberhasilan pendidikan sebagian besar ditentukan oleh kinerja guru dalam dunia pendidikan. Penelitian ini bertujuan menguji kontribusi kompetensi guru dan peran motivasi dalam menentukan kinerja guru. Populasi dalam penelitian ini adalah guru Yayasan Pendidikan GMI Imanuel sebanyak 74 orang. Instrumen yang dipakai dalam penelitian ini adalah kuesioner tertutup, diuji dengan uji validitas dan reliabilitas. Dalam penelitian ini ada beberapa metode analisis yang digunakan yaitu analisis diskriminan, analisis cluster, Regresi, dan Path Analysis. Hasil penelitian dari analisis cluster menunjukkan bahwa pada tingkat TK,SD,SMP, dan SMA populasi terbanyak guru yang memiliki sikap positif terhadap variable kinerja guru. Hasil penelitian dari path analysis menunjukkan bahwa hipotesis penelitian diterima dalam arti bahwa terdapat kontirbusi secara signifikan diantara eksogen variable dan endogen variable.
\end{abstract}

Kata kunci: latar belakang, organisasi, motivasi, kompetensi guru, kinerja 


\section{PENDAHULUAN}

\section{Latar Belakang}

Keberhasilan pendidikan sebagian besar ditentukan oleh kinerja guru dalam dunia pendidikan. Disamping sekolah sebagai lembaga pendidikan bertugas untuk mencerdaskan bangsa tetapi juga sekolah menghadapi beban berat yakni menjaga keberlangsungan sekolah tidak hanya untuk bertahan dari persaingan tetapi juga mengembangkan sekolah.

Menurut kepala Dinas Pendidikan DKI Jakarta Dr. Taufik Yudi Mulyoto, MPd. (Mulyoto, 2009), pada tahun 2009 jumlah sekolah di Jakarta mulai SD (Sekolah Dasar) hingga SMA/SMK mencapai 5.005 buah. Jumlah Sekolah Dasar Negeri (SDN) di Jakarta sebanyak 2.244 buah dengan jumlah peserta didik mencapai 670.599 murid dan SD Swasta sebanyak 753 buah dengan 192.323 murid. Jumlah SMP Negeri yang ada di DKI Jakarta mencapai 306 sekolah dengan 227.722 pelajar dan SMP swasta sebanyak 631 buah dengan jumlah pelajar 135.464 orang. Sementara, jumlah Sekolah Menengah Atas Negeri (SMAN) sebanyak 116 buah dengan 91.886 siswa dan SMA Swasta sebanyak 381 buah dengan jumlah siswa 85. 731 orang. Tercatat 62 buah Sekolah Menengah Kejuruan Negeri (SMKN) di Jakarta dengan jumlah siswa sebanyak 41. 830 orang dan SMK Swasta sebanyak 512 buah dengan 157.751 siswa. Dengan banyaknya jumlah sekolah swasta dan negeri di Jakarta maka salah satu variabel penting sebagai daya saing yang perlu dikembangkan adalah Kinerja guru.

Tujuan Penelitian ini antara lain mengetahui kontribusi Latar Belakang Guru $\left(\mathrm{X}_{1}\right)$ terhadap Kompetensi Guru (Y) dan dampaknya pada Kinerja Guru (Z), mengetahui kontribusi Organisasi $\left(\mathrm{X}_{2}\right)$ terhadap Motivasi $\left(\mathrm{X}_{3}\right)$ dan Dampaknya pada Kinerja Guru $(\mathrm{Z})$ dan mengetahui kontribusi Organisasi $\left(\mathrm{X}_{2}\right)$ terhadap Kompetensi Guru (Y) dan dampaknya pada Kinerja Guru (Z) di Yayasan Pendidikan GMI Indonesia.

Kerangka pemikiran dalam penelitian ini, yaitu seperti pada Gambar 1.

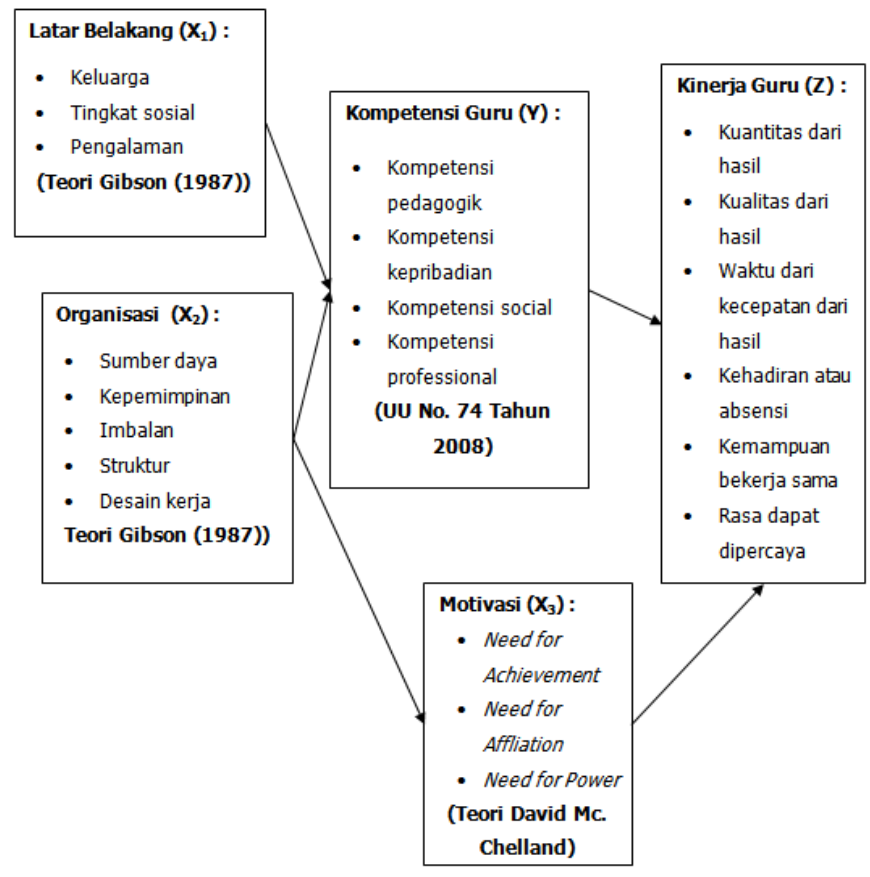

Gambar 1 Kerangka teori 
Pada Gambar 1, dijelaskan tentang dasar-dasar penelitian sebelumnya. Teori Gibson (1987) yang dikutip oleh (Illyas, 1999; Indrawati, 2006), ada tiga kelompok variabel yang mempengaruhi perilaku kerja dan kinerja yaitu: variabel individu, variabel organisasi dan variabel psikologis. Diagram skematis variabel yang mempengaruhi perilaku dan kinerja.

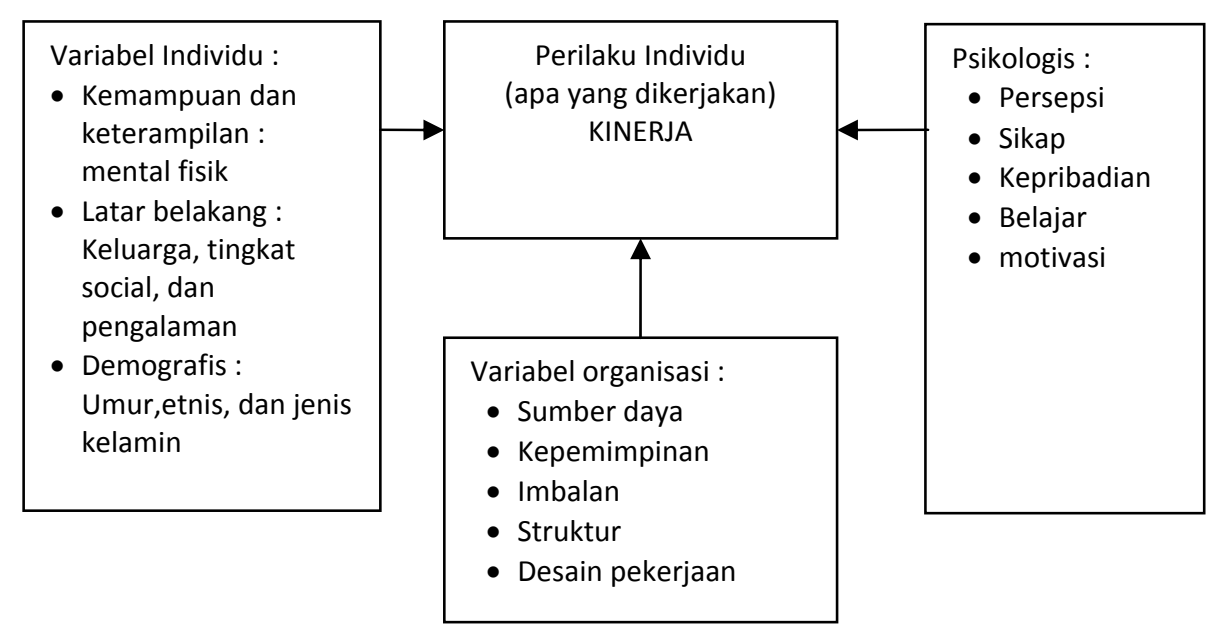

Gambar 2 Teori Gibson

Variabel individu dikelompokkan pada sub-variabel kemampuan dan ketrampilan, latar belakang dan demografis. Sub-variabel kemampuan dan ketrampilan merupakan faktor utama yang mempengaruhi perilaku dan kinerja individu. Variabel demografis, mempunyai efek tidak langsung pada perilaku dan kinerja individu. Variabel psikologik terdiri dari sub-variabel persepsi, sikap, kepribadian, belajar, dan motivasi. Variabel ini banyak dipengaruhi oleh keluarga, tingkat sosial pengalaman kerja sebelumnya dan variabel demografis. Variabel psikologis seperti persepsi, sikap, kepribadian, dan belajar merupakan hal yang komplek dan sulit diukur. Variabel organisasi berefek tidak langsung terhadap perilaku dan kinerja individu. Variabel organisasi digolongkan dalam subvariabel sumber daya, kepemimpinan, imbalan, struktur, dan desain pekerjaan.

\section{METODOLOGI PENELITIAN}

\section{Teknik dan Pengumpulan Data}

Menurut Nasution (2003) mengemukakan dalam bukunya, mutu penelitian tidak selalu ditentukan oleh besarnya sampel, oleh kokohnya dasar-dasar teori, oleh desain penelitiannya (asumsiasumsi statistik), serta mutu pelaksanaan dan pengolahannya. Maka apabila subjek penelitian kurang dari 100, lebih baik diambil semua, sehingga penelitiannya merupakan penelitian populasi. Dengan memperhatikan pernyataan diatas, karena jumlah populasi dari penelitian ini adalah guru di sekolah Methodist yang berjumlah 74 orang sehingga penelitian ini tidak menggunakan sampel dan merupakan penelitian populasi.

\section{Rancangan Uji Hipotesis}

Hipotesis yang diuji dalam penelitian ini adalah: (1) Untuk T-1, Ho: latar belakang, kompetensi guru tidak berkontribusi secara signifikan terhadap kinerja guru, Ha: latar belakang, kompetensi guru berkontribusi secara signifikan terhadap kinerja guru; (2) untuk T-2, Ho: organisasi dan motivasi tidak berkontribusi secara signifikan terhadap kinerja guru, Ha: organisasi dan motivasi berkontribusi secara signifikan terhadap kinerja guru; (3) untuk T-3, Ho: organisasi, kompetensi guru 
tidak berkontribusi secara signifikan terhadap kinerja guru, Ha: organisasi, kompetensi guru berkontribusi secara signifikan terhadap kinerja guru.

\section{Gambaran Umum Profile Guru di GMI Immanuel}

Profil guru di Yayasan Pendidikan GMI Immanuel mayoritas adalah wanita dan berusia antara 20-30 tahun serta memiliki pengalaman menjadi guru lebih dari 5 tahun. Hal itu menunjukkan bahwa pendidik di GMI adalah wanita yang energik dan memiliki cukup pengalaman.

\section{PEMBAHASAN}

Berdasarkan analisis dengan alat statistic discriminan yang membedakan tingkatan guru TK, SD, SMP, dan SMA diperoleh penjelasan bahwa guru tingkat TK memiliki sikap positif terhadap variable organisasi dan kompetensi guru, mereka cenderung berfokus pada penguasaan terhadap pengetahuan, keterampilan, nilai, sikap, dan tujuan organisasi/bersama. Pada tingkat SD memiliki sikap positif terhadap variable kinerja guru dan organisasi, mereka cenderung berfokus pada out-come yang dihasilkan dan tujuan organisasi/bersama. Pada tingkat SMP memiliki sikap positif terhadap variable Organisasi dan Kinerja Guru. Dan cenderung berfokus pada tujuan bersama dan out-come yang dihasilkan. Pada tingkat SMA memiliki sikap positif terhadap variable Organisasi dan Kinerja Guru. Dan cenderung berfokus pada tujuan organisasi dan out-come yang dihasilkan.

Temuan ini menyatakan bahwa TK,SD,SMP, dan SMA berpendapat positip terhadap variable Organisasi, yang berarti bahwa Yayasan Pendidikan GMI Imanuel sudah berhasil memiliki suatu standart organisasi dalam hal menentukan sumber daya, kepemimpinan, imbalan, struktur, dan desain kerja untuk seluruh tingkatan pendidikan. Guru di tingkat SD, SMP, dan SMA berpendapat positip terhadap kinerja, yang berarti Guru ditingkat SD, SMP dan SMA lebih memperhatikan Kuantitas dari hasil, Kualitas dari hasil, Waktu, Kehadiran atau absensi, Kemampuan bekerja sama, dan Rasa dapat dipercaya. Kinerja ini tentunya sangat mendukung daya saing pendidikan di GMI Immanuel dimana tuntutan kualitas pendidikan di tingkatan SD, SMP, SMA saat ini menggunakan persyaratan nilai standard minimal kelulusan untuk melanjutkan ke jenjang berikutnya dan telah diberlakukan di seluruh pendidikan SD, SMP, dan SMA di Indonesia. Guru SD, SMP, dan SMA GMI Immanuel menunjukkan upaya yang keras agar memiliki daya saing tersebut. Sedangkan pada guru TK berpendapat positip terhadap kompetensi guru. Hal ini dapat dimaklumi karena tuntutan guru TK membutuhkan kompetensi mendalam yang lebih fokus pada kepribadian dasar, pedagogic, social dan proffesionalitas guru yang sangat mengerti akan kemampuan anak-anak yang masih sangat mendasar sekali. Gambaran umum Guru di GMI Immanuel meskipun berbeda fokus dalam hal kinerja dan kompetensi namun mayoritas guru telah bekerja sesuai dengan tuntutan tingkatan pendidikan yang diembannya.

Setelah diperoleh gambaran perbedaan perhatian guru berdasarkan tingkatan mengajarnya maka selanjutnya diperlukan gambaran khusus mengenai pengelompokan perhatian guru terhadap variable penelitian yakni, latar belakang guru, organisasi, motivasi, kompetensi, dan kinerja. Untuk dapat mengelompokkan fokus perhatian guru, maka diperlukan analisis cluster. Diperoleh gambaran sebagai berikut: (1) pada kluster 1, kelompok ini lebih memperhatikan kinerja guru dan cenderung fokus datang ke tempat kerja tepat waktu; (2) pada kluster 2, kelompok ini lebih memperhatikan kinerja guru dan cenderung fokus pada kekompakan team yakni mampu dipercaya dengan baik oleh rekan kerjanya; (3) pada kluster 3, kelompok ini lebih memperhatikan kompetensi guru dan cenderung fokus pada pemahaman secara mendalam setiap materi pelajaran yang diajarkan; (4) pada kluster 4, kelompok ini lebih memperhatikan kinerja guru dan cenderung fokus menghasilkan pekerjaan dengan kualitas yang maksimal. 
Dengan demikian diketahui bahwa terdapat 3 kelompok guru yang memiliki karakteristik sama memperhatikan kinerja namun berbeda orientasi. Perbedaan orientasi antara lain: datang tepat waktu, dipercaya rekan kerja, dan menghasilkan pekerjaaan dengan kualitas maksimal. Kelompok Guru pengajar tingkatan SD, SMP, dan SMA berada pada cluster 1, 2, dan 4, yang merupakan kelompok yang memperhatikan kinerjanya dan memiliki karakteristik utama yakni bekerja dalam team, kedua yakni mementingkan kedisiplinan dan ketiga yakni pekerja keras, Sedangkan Guru pengajar tingkat TK adalah kelompok guru yang memperhatikan kompetensinya dengan mempelajari secara mendalam materi yang diajarkan. Dengan pengelompokan ini dilakukan pendekatan karakter kelompok dalam mempersiapkan pelatihan yang sesuai dengan kelompok tersebut. Guru SD, SMP dan SMA paling tepat diberikan pelatihan yang bersifat bekerja dalam team, disiplin, dan materi pelatihan untuk meraih usaha yang maksimal. Sedangkan kelompok guru TK diberikan pelatihan yang mengarah pada materi pembelajaran.

Demi meningkatkan kinerja guru maka diperlukan analisis penentu kinerja guru. Analisis jalur digunakan untuk mengetahui keterlibatan dan keterkaitan secara langsung maupun tidak langsung antara latar belakang guru, organisasi, motivasi, dan kompetensi terhadap kinerja guru. Diperoleh penjelasan bahwa latar belakang dan kompetensi guru berkontribusi secara signifikan terhadap Kinerja Guru, hal ini menunjukkan bahwa latar belakang guru secara bersama-sama dengan kompetensinya dapat menentukan kinerjanya. Berikutnya dapat dijelaskan bahwa Latar belakang guru dapat menentukan kompetensi guru itu sendiri.

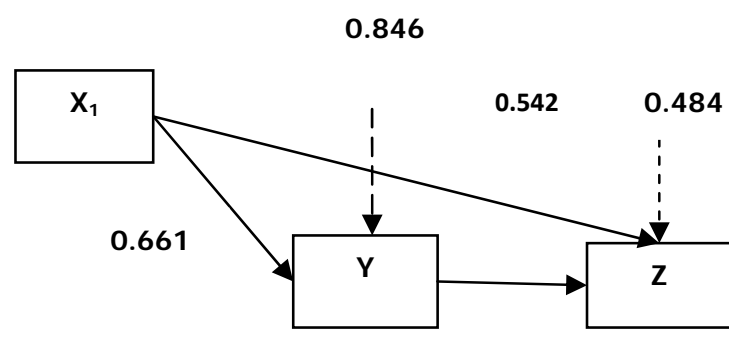

0.305

Gambar 3 Sub-Struktur 1

Nilai koefisien jalur yang telah diperoleh melalui analisa jalur model sub-struktur 1 menunjukkan bahwa latar belakang seorang guru menentukan kompetensinya yang akan berdampak besar bagi kinerja. Kinerja guru tidak hanya ditentukan oleh latar belakang saja, tetapi juga ditentukan oleh organisasi dan motivasi. Organisasi secara signifikan mampu menciptakan motivasi yang berdampak pada kinerja guru. Nilai koefisien jalur yang telah diperoleh melalui analisis jalur model sub-struktur 2 adalah:

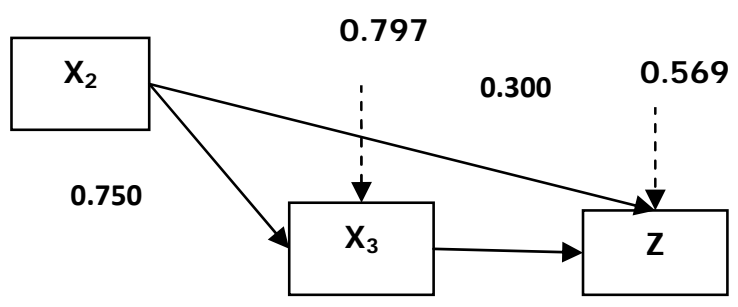

0.464

Gambar 4 Sub-Struktur 2 
Bila dibandingkan pengaruh tidak langsung antara latar belakang melalui kompetensi yang berdampak pada kinerja dengan pengaruh tidak langsung antara organisasi melalui motivasi yang berdampak pada kinerja, maka dapat diketahui bahwa latarbelakang lebih besar pengaruh tidak langsungnya terhadap kinerja daripada peran organisasi dalam menciptakan motivasi yang berdampak pada kinerja. Selanjutnya perlu diketahui pengaruh tidak langsung organisasi terhadap kinerja namun melalui penciptaan kompetensi. Nilai koefisien jalur yang telah diperoleh melalui analisis jalur model sub-struktur 3 adalah:

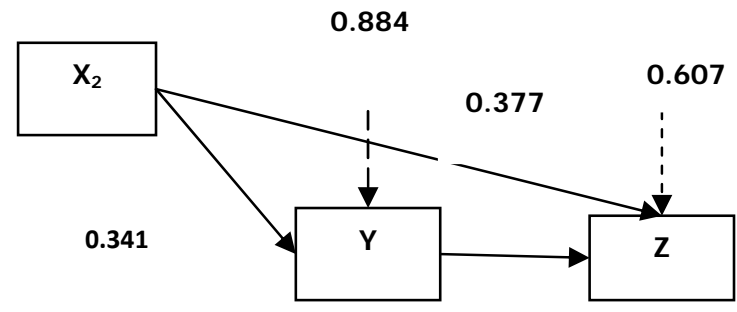

0.389

Gambar 5 Sub-struktur 3

Organisasi sebagai suatu wadah sumber daya berperan mengembangkan kepemimpinan, imbalan, struktur kerja dan design kerja juga dapat berpengaruh secara bersama-sama dengan kompetensi guru untuk menghasilkan kinerja yang baik. Organisasi yang baik akan mampu menciptakan kompetensi yang baik juga, Karena sesungguhnya dalam organisasi menentukan interaksi pengetahuan, keterampilan, sikap dan nilai yang pada akhirnya berdampak pada kinerja guru. Guru yang berkompeten akan mampu menentukan kinerja guru yang baik. Namun pengaruh organisasi secara tidak langsung terhadap kinerja melalui kompetensi adalah pengaruh terkecil dibandingkan latar belakang melalui kompetensi, dan organisasi melalui motivasi.

Model akhir menunjukkan bahwa terdapat pengaruh yang signifikan antara x1 (latar belakang) terhadap y (kompetensi) dan dampaknya pada z (kinerja). Terdapat pengaruh yang signifikan antara x2 (organisasi) terhadap y (kompetensi) dan dampaknya pada z (kinerja). Terdapat pengaruh yang signifikan antara x2 (organisasi) terhadap x3 (motivasi) dan dampaknya pada z (kinerja), seperti pada Gambar 6.

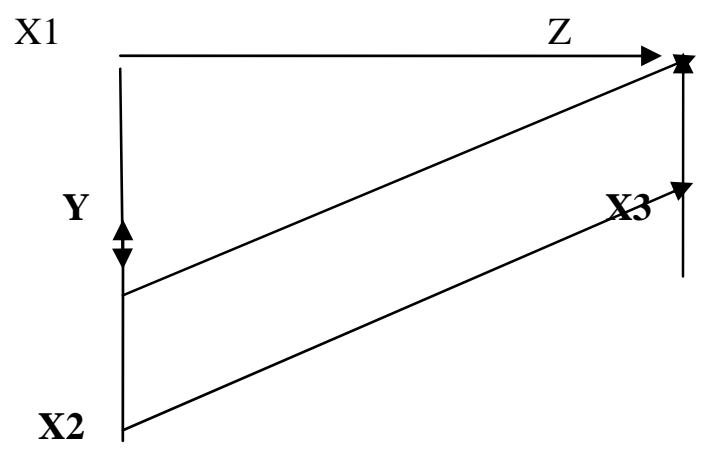

Gambar 6 Model akhir

Hal ini menunjukkan bahwa Latar belakang guru sangatlah penting dalam menentukan kinerja guru itu sendiri. Namun juga perlu untuk mempertimbangkan bahwa Outcome yang dihasilkan oleh pegawai juga ditentukan oleh kelompok orang dalam suatu wadah untuk memotivasi anggotanya mencapai tujuan bersama. Dan organisasi tetap diharapkan mampu untuk mensinergikan kompetensi gurunya untuk dapat menghasilkan kinerja yang baik. 


\section{PENUTUP}

Latar belakang guru berpengaruh secara langsung maupun tidak langsung terhadap kinerja guru. Latar belakang guru yang baik akan mampu menciptakan kompetensi yang baik untuk dapat meningkatkan kinerja guru. Hal ini bisa menjadi pertimbangan utama dalam merekrut guru baru yakni dengan pertimbangan utama latar belakang guru itu sendiri. Organisasi juga dapat menghasilkan kinerja guru yang baik karena organisasi dapat berperan sebagai wadah pembentukan motivasi dan pembentukan kompetensi guru yang mampu meningkatkan kinerja guru. Yayasan sebagai organisasi yang menciptakan motivasi dan kompetensi perlu mengadakan training yang dibutuhkan guru-gurunya yakni training yang terkait dengan kinerja guru dan kompetensi. Subjek training dapat berupa pelatihan creating an inspiring classroom (menciptakan kelas yang menginspirasi). Pelatihan ini akan sangat cocok dengan kelompok guru SD, SMP, SMA yang mengutamakan kerja tim. Subjek training super creative teacher, (guru super kreatif) akan sangat sesuai pada kelompok guru SD, SMP dan SMA untuk dapat bekerja sebagai guru dengan usaha yang maksimal. Subjek training managing change in the school, (mengelola perubahan di sekolah) akan sangat sesuai untuk kelompok guru SD, SMP dan SMA yang selalu mengembangkan kedisiplinan. Sedangkan untuk Guru TK diperlukan subject training terkait dengan story-telling, English introduction atau materi lain yang mendukung pembentukan kepribadian anak.

\section{DAFTAR PUSTAKA}

Ilyas, Y. (1999). Kinerja. Depok: Badan Penerbit FKM UI.

Indrawaty, Y. (2006). Faktor-faktor yang mempengaruhi kinerja guru matematika dalam pelaksanaan kurikulum berbasis kompetensi (KBK) pada Sekolah Menengah Atas Palembang. Jurnal Manajemen \& Bisnis Sriwijaya Vol. 4, No. 7, Juni 2006. Diunduh dari http://digilib.unsri.ac.id/download/Jurnal\%20MM\%20Vol\%204\%20No\%207\%20Artikel\%20 3\%20Yuliani\%20Indrawaty.pdf

Mulyoto, T. Y. (2009). Jumlah sekolah di Jakarta. Diakses dari http://disdikdki.net/news.php?cat=1\&id=122

Nasution. (2003). Metode research (penelitian ilmiah). Jakarta: Bumi Aksara. 